UNITED STATES DEPARTMENT OF THE INTERIOR

Harold L. Ickes, Secretary

GEOLOGICAL SURVEY

W. E. Wrather. Director

Bulletin 946-D

\title{
TUNGSTEN DEPOSITS OF THE SOUTTHERN PART OF SONORA, MEXICO
}

\author{
BY \\ JOHN H. WIESE \\ IN COLLABORATION WITH \\ SALVADOR CARDENAS \\ Prepared in cooperation with the
}

SECRETARIA DE LA ECONOMIA NACIONAL, DIRECCION

GENERAL DE MINAS Y PETROLEO and UNIVERSIDAD NACIONAL DE MEXICO. INSTITUTO DE GEOLOGIA

under the auspices of

INTERDEPARTMENTAL COMMITTEE ON CULTURAL AND

SCIENTIFIC COOPERATION, DEPARTMENT OF STATE

Geologic Investigations in the American Republies, $1944-45$

(Pagea 103-130)

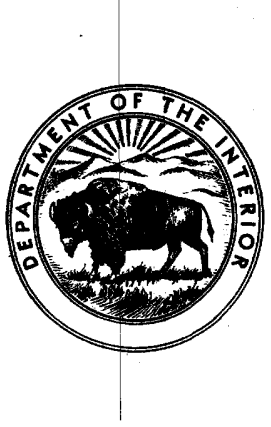

UNITED STATES

GOVERNMENT PRINTING OFFICE

WASHINGTON : 1945

For sale by the Superintendent of Documenks. U. S. Government Printing Ofice, Washington 25, D. C Price 15 cents 


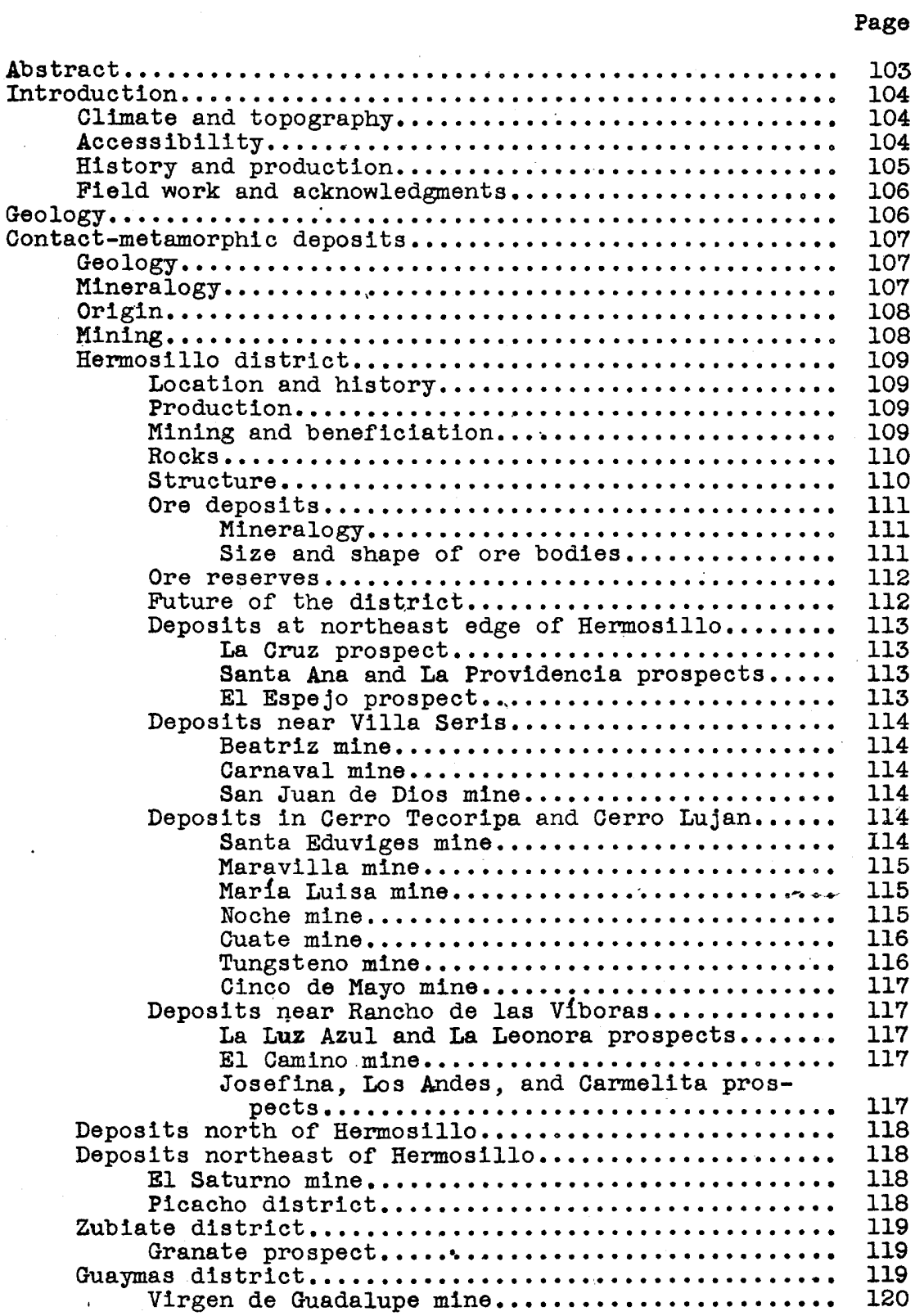


Contact-metamorphic deposits - Continued

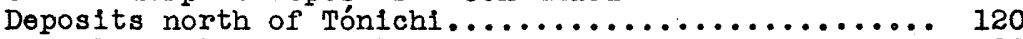

Tecolote prospect...................... 120

Extensión de Uranio prospect............... 120

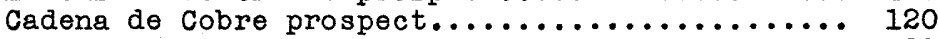

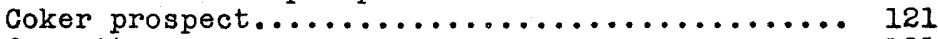

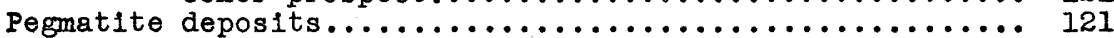

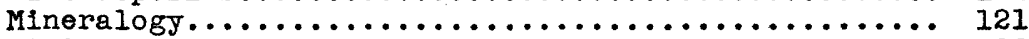

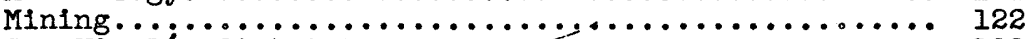

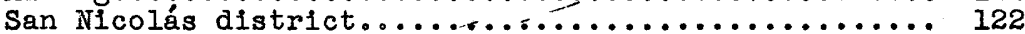

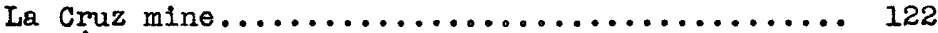

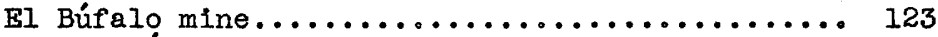

San Julián mine.................... 124

Other properties in the San Nicolás district.... 124

El Encinal district....................... 124

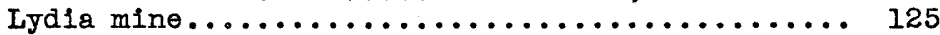

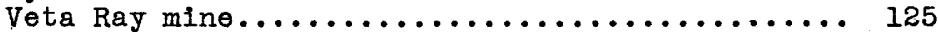

Other properties in the El Encinal district..... 125

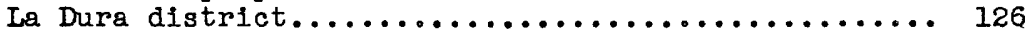

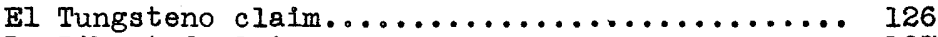

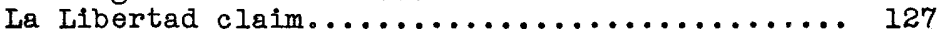

Other prospects in the La Dura district........ 127

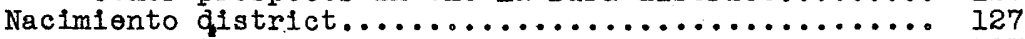

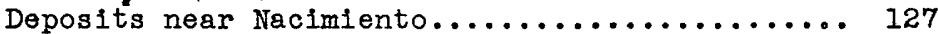

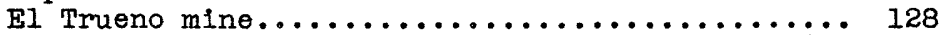

Llano Colorado deposit.................... 128

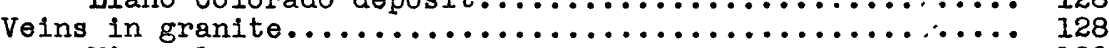

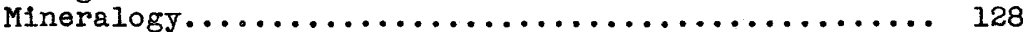

Tecoripa district...................... 129

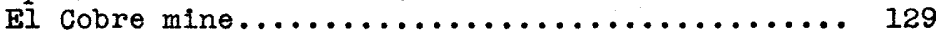

La Paz deposit...................... 130

ILLUSTRATIONS

Page

Plate 39. Index map of the southern part of the state of Sonora, Mexico, showing tungsten depos-

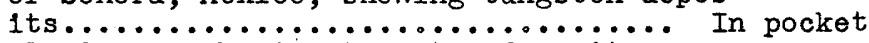

40. Geologic map showing tungsten deposits near

Hermosillo, Sonora, Mexico........... In pocket

41. Geologic maps of the Carnaval, San Juan de Dios, Santa Eduviges, and Maravilla mines, Hermosillo district, Sonora, Mexico... In pocket

42. Geologic maps of the Marla Luisa, Noche, Cuate, and Tungsteno mines, Hermosillo district, Sonora, Mexico............. In pocket

43. Geologic maps of the Cinco de Mayo and Camino mines, Hermosillo district, Sonora, Mexico........................... In pocket

44. Geologic map of the Nublado claim, Picacho district, Sonora, Mexico........... In pocket 


\section{IILUSTRATIONS}

Page

Figure 15. Geologic map of the Virgen de Guadalupe mine, Guaymas district, Sonora........... 119 16. Geologic section through El Tungsteno

claim, La Dura, Sonora.............. 126

17. Geologic sketch map of El Cobre mine, Tecoripa district, Sonora.............. 130

TABLE

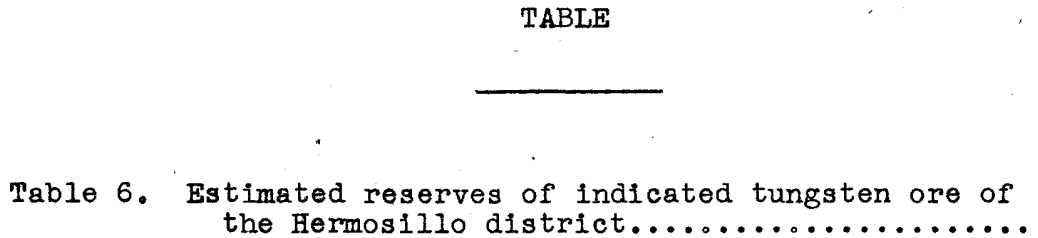

Page

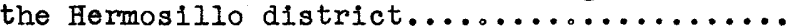


TUNGSTEN DEPOSITS OF THE SOUTHERN PART

OF SONORA, MEXICO

By John H. Wiese

in collaboration with

Salvador Cárdenas

ABSTRACT

Tungsten deposits occur in more than 20 localities in the southern part of the state of Sonora, Mexico. The ore bodies are of three types: (1) contact-metamorphic deposits in Iimestone, (2) pegmatite dikes in granite, and (3) quartz veins in granite. Production of tungsten was first recorded in 1916; since then a total of 100,000 short ton units 1 / of WO3 has probably been produced in this region, although accurate production figures are not obtainable. Most of the production has come from the area drained by the Yaqui River, but in 1943 some production came from deposits near Hermos1110.

Low-grade contact-metamorphic deposits are found throughout the region, but the most important deposits of this type are in the vicinity of the town of Hermosillo. In these deposits scheelite (CaWO 4 , calcium tungstate) occurs disseminated in tactite composed of garnot, epidote, quartz, and calcite, with minor amounts of fluorite, pyrite, chalcopyrite, and powellite. No facilities for the beneficlation of low-grade tungsten ores are available closer than Nogales, Sonora, and work has therefore been discontinued at many of these deposits. However, they constitute the larger part of the reserves of tungsten ore in the southern part of Sonora.

The pegmatite dikes occur mainly in the eastern part of the region, at the margins of many small areas of granite outcrop. The dikes consist of quartz, feldspar, and mica, and contain various proportions of scheelite, cuprotungstite, molybdenite, powellite, pyrite, and chalcopyrite. The scheelite occurs as kidney-shaped masses, clusters of crystals, or as stringers:

The two known deposits of tungsten associated with quartz veins are in the Tecoripa district, where steeply dipping veins of quartz and calcite, arranged en echelon, lie near the borders of intrusive bodies of granite. In addition to scheelite, the veins contain pyrite, chalcopyrite, gold, and molybdenite. No tungsten has been produced from these deposits, but their reserves are important.

I/ A short ton unit is 20 pounds of tungsten trioxide $\left(\mathrm{rO}_{3}\right)$. 


\section{INTRODUCTION}

Tungsten deposits are known in many parts of Mexico, but almost all of the tungsten ore mined in Mexico has come from the States of Sonora and Sinaloa and the Territory of $\mathrm{Baja} \mathrm{Cal-}$ ifornia. The locations of the known deposits of the southern part of Sonora are shown on the map, plate 39. The tungstenbearing area extends east from a Iine between Hermosillo and Guaymas almost to the border of Chihuahua, and more than half of the deposits are in the area drained by the Yaqui River and lts tributaries.

\section{Climate and topography}

Eastward from Hermosillo almost to the Yaqui River is a desert region of detached mugged hills and ridges separated by broad areas of low relief, many of which are in large part pediment. The Yaqui River region is one of north-trending parallel ranges and valleys, with altitudes ranging from 180 meters at Tónichl, on the Yaqui River, to about 1,500 meters at $S a n$ Nicolás. East of San Nicolás is the region of deep westwarddraining barrancas along the edge of the Sierra Madre Occidental.

The climate of most of Sonora is much like that of southwestern Arizona. The winters are short, and from May to September fleld work is slowed by the high temperatures. Most of the precipitation comes in short, heavy, local rains between the end of June and the first of october. Other more widespread and prolonged rains come during December and January.

\section{Accessibility}

The main line of the Sud Pacifico de México Railroad, connecting Nogales, Ariz., with Guadalajara, lies along the west coast of Mexico and passes through Hermosillo and Guaymas. From Corral, where the rallroad crosses the Yaqui River, a branch line leads up the west bank of the Yaqui to Tónich1.

A gravel highway, passable except during heavy rains, connects Nogales, Hermosillo, and Guaymas. Dirt roads lead eastward from Hermosillo to Ures and to Soyopa, and a road to Tónichl through La Colorada has recently been improved to within a few kilometers of Tecoripa. There is no road between Tónichl and La Dura, and La Dura can be reached by automobile only from Cludad Obregón or Navojoa. A graded truck road muns east from La Dura to the lumbering camps at Campanero, on the Chihuahua border, passing within 25 kilometers of San Nicolás. Another truck road connects Tónichi with Bacanora and Sahuaripa. Travel during the rainy season is difficult, as only a few arroyos are crossed by bridges and the low ground is generally boggy.

The Yaqui River carries water throughout the year but is not deep enough to be navigable even for barges. It can be crossed at Soyopa, Tónichl, and Corral by means of ferries, and over a light suspension bridge at La Dura. The Sonora River carries water only during the summer rainy season, but has many shallow pools along its course the rest of the year. Wells along its banks reach the water table at depths only a few 
meters below the channel bottom. Many of the canyons east of the Yaqui River have permanent streams, but west of the river the arroyos are dry most of the year.

\section{History and production}

Tungsten was first found in southern Sonora in the pegmatite dikes of the San Nicolás region shortiy before World War I. Stimulated by the high prices paid for concentrates at that time, active prospecting in the granitic ared drained by the Yaqui River resulted in the discovery of many small concentrations of tungsten ore, both in bedrock and as placers. During World War $I$, nearly ail the tungsten produced in southern Sonora came from three mines: the La Cruz at San Nicolas, the San Julián at Santa Ana, and the El Trueno near Nacimiento.

The La Cruz, by far the largest mine in the region, then operated by James Douglas, is reported to have produced 1,000 tons of concentrates from 1917 to 1919. The San Jullán is sald to have produced $\$ 250,000$ worth of molybdenum concentrates, and some tungsten was very probably recovered as well. Frank Fast reports that he and his father produced $35-40$ tons $2 /$ of concentrates during 1916 and 1917 from the EI Trueno mine before shutting down because of impending trouble with the Yaqui Indians.

In the years following the Armistice, interest in tungsten lagged until 1929, when Frank Fast reopened the La Cruz mine and began buying concentrates in the San Nicolás district.

Fast produced 72 tons of $\mathrm{WO}_{3}$ concentrates from the San Julián mine during 1929 and 1930, and 216 tons from the La Cruz mine from 1929 to 1935 , although the latter mine was shut down from 1931 to 1933. From 1935 to 1942 the La Cruz mine and dumps yielded from 1 to 3 tons of concentrates per month under the ownership of Emilio Bouvet of Navojoa.

The beginning of World War II brought on a renewed search for tungsten, resulting in the discovery in January 1943 of tungsten deposits of contact-metamorphic type at many places within a few kilometers of Hermosillo, the capital of Sonora. only deposits of the pegmatite type had been known before then, and prospecting had been confined to the areas of granite outcrop. Later in 1943 other contact-metamorphic tungsten deposits were located, nearly all of them west of the Yaqui River, most within 60 kilometers of Hermosillo.

In 1942 and 1943 production from dry placer operations in the Yaqui River region amounted to about 100 tons of concentrates.

The gambusinos 3/ who work the placer deposits move from one district to another, and production from any one district fluctuates with the number of men working there. It is estimated that from 400 to 500 men were engaged in this occupation in southern Sonora in the spring of 1943 .

2f Tonnage Ilgures in this report are in short tons.

3/ Gambusinos ere miners who, singly or in smell groups, work the pay streaks of a property which could not be mined profitably by large-scale methods. They generally work by permission of the owners of the property. and sell their ore or concentretes to him or to free-lence buyers. 
The mines in the Hermosillo region yielded about 3,000 units of $\mathrm{WO}_{3}$; about a third of this amount was in the form of concentrates and the remainder, shipping ore.

\section{Field work and acknowledgments}

The field work upon which this report is based extended from January to November of 1943 as part of the Program for Cooperation with the American Republics, sponsored by the Department of State. In Mexico, this program, carried out by the Geological Survey and the Dirección de Minas y Petróleos, entails close cooperation in the field between representatives of the two agencies. Ing. Salvador Cárdenas, of the Dirección de Minas $\mathrm{y}$ Petroleos of the Economla Nacional, collaborated with the writer in the field work from January to April 1943, and much of the success of the project was due to his enthusiastic cooperation. The staff of the Instituto Geológico of Mexico and of the Bconomic Section of the U. S. Embassy in Mexico alded in many ways, and their help was much appreciated.

Space does not permit naming all those who alded in the field, but particular thanks must be given to James E. Coker, Howard H. Fields, Mark Fowler, Pedro J. Fruns, A. F. Johnson, M. S. McCarthy, Ricardo R. Melendrez, Eduardo Muñoz, Juan Roblnson, Blás F. Salazar, J. P. Sanders, and William C. Taylor, Jr., all of whom gave generously of their time and assistance. Thanks are also due to the many Mexican miners and ranchers who supplied much information and acted as guides.

Mary Elizabeth Dorr and James F. McAllister, of the Geological Survey, offered many helpful suggestions and criticisms during the preparation of the report.

\section{GEOLOGY}

The geology of the southern part of Sonora has been well described by King 4 / of Sonora. Paleozoic limestones, Triassic and Jurassic quartzite and shale, and Cretaceous limestones are overlain by Cretaceous and Tertiary volcanic rocks, mostly andesite and basalt. The intmusive rocks are probably of Tertiary age and include granite and some quartz porphyry and rhyolite.

The structure of the rocks is complex. Normal and thrust faults with a general north trend have broken the rocks into a number of subparallel blocks now carved by erosion into a series of north-striking ridges and valleys.

All the tungsten deposits and most of the mineral deposits of southern Sonora are directly related to the granite intrusives. Small areas of granite crop out in many places throughout the area, and it is likely that the whole of southern Sonora is underlain by a batholith of Tertiary age, the roof of which was very near the present land surface, partiy above and partly below it.

4/ King, R. E., Oeologicel reconnalssance in northern Sierra ladra Occidental of Mexico: Ceol. Soc. America Bull., vol. 50, no. 11, pp. 16251722, 1939. 
The tungsten deposits are of three types: (1) contactmetamorphic deposits in limestone, (2) pegmatite deposits, and (3) deposits in quartz veins in granite. The known placer concentrations were derived from deposits of the pegmatite type. Scheelite is the only tungsten mineral found in southern Sonora; in northern Sonora, however, considerable quantities of wolframite have been mined.

\section{CONTACT-METAMORPHIC DEPOSITS}

Contact-metamorphic deposits were first discovered in southern Sonora in January 1943, in the vicinity of Hermosillo. Most of the known contact deposits are within a radius of 60 kilometers of Hermosillo; others are near Guaymas, Sahuaripa, and Bacanora. Little tungsten was produced from these deposits in 1943 and, because of the uncertainty of the tungsten market during the closing months of that year, work was stopped on most of them. The largest part of the known reserves of tungsten ore in southern Sonora is contained in these deposits; in consequence they were studied in greatest detall.

\section{Geology}

The limestone host rock of the contact-metamorphic tungsten deposits is believed to be paleozolc in age. It is gray and well stratifled, and contains some interbedded shale. King 5/ has identified ilmestones of Ordovician and Permian age in the region, and believes that some of the unfossiliferous strata are of middle Paleozolic age.

The granite which has intruded and metamorphosed the Iimestone is probably the same as that containing the pegmatite and the vein deposits: A few.small scheelite-bearing pegmatite bodies occur with the contact-replacement ore bodies in the Hermosillo district.

\section{Mineralogy}

The mineralogy of these deposits is typical of that of many contact-metamorphic tungsten deposits in the United States.6/ Three zones may be distinguished, from the granite outward into the limestone: (1) a well-defined zone of dark silicate minerals, forming "tactite" rock, extending from a few centimeters to as much as 100 meters from the granite contact, (2) a zone of Iight-colored silicate minerals extending as much as several hundred meters from the contact and grading imperceptibly into zone (3), in which the limestone and its impurities are recrystallized without addition of material from the intmisive.

Scheelite is found only in the tactite, although not all tactite contains. scheelite. The tactite is made up of various proportions of garnet, epldote, quartz, calclte, scheelite, hornblende, idocrase, fluorite, pyrite, molybdenite, and chalcopyrite. Its color is usually dark red or green, depending-

5/ King, R. I., op. c1t., pp. 1641-1645.

6/ Hess, F. I., and Larsen, E. S., Contect-metamorphic tungsten deposits of the United States: U. S. Ceol. Survey Bull. 725, pp. 251-255, 1920. 
on whether garnet or epidote is the predominant mineral. It is heavy, hard, and in many cases is very resistant to erosion.

The light-colored silicate zone contains calcite, tremolite, wollastonite, idocrase, and diopside. In the outer zone the only silicate minerals are those formed by the recrystallization of material originally present in the limestone.

\section{Origin}

During the later stages in the emplacement of the intrusive igneous body, heated solutions bearing silica, fron, and alumina, as well as lesser amounts of other metals, were given off by the cooling magma. Apparently the granite adjacent to the contact was the first part to cool, and readjustments along its outer edge caused fracturing and fissuring between it and the limestone, forming channelways for the rising solutions. The limestone at the contact was replaced first, and in places the replacing solutions moved outward into the limestone along fissures or along certain permeable limestone beds. Thus the ore bodies are found directiy at the contact between Iimestone and granite or in the limestone a short distance away from the contact, where chemical and physical conditions were favorable for replacement.

\section{Mining}

In many places in southern Sonora, the hardness of the scheelite-bearing tactite makes mining of these deposits by the hand methods employed both costly and laborious. The tactite at the Nublado prospect, for example, is so hard that a man using hand steel requires two days to drill a blasting hole 50 centimeters long. In parts of the Hermosillo district, however, the tactite contains a large proportion of easily weathered calcite, and the garnet and quartz in the rock have been shattered by faulting. As a result, the ore is softer than the surrounding granite and limestone and is easily mined.

The only mill for beneficlating tungsten ores in southern Sonora is one of 3 tons capacity which processes ore from the María Iuisa mine at Hermosillo. Ore from all the other deposits must be sorted to attain a grade of about 2.0 percent of WO $_{3}$ to pay the costs of shipping to Nogales, Sonora, for milling. Sorting is usually done by hand, under ultraviolet light. The softer tactite ore is passed over a screen of I centimeter mesh and, as the scheelite is soft and friable, a higher proportion of it is found in the fines. By screening alone ore of 1 percent grade can be brought up to a grade of 2 to 3 percent of $\mathrm{WO}_{3}$.

No placer mining has been attempted in the washes adjacent to any of the contact-metamorphic tungsten deposits, nor have the washes been prospected for placer scheelite. When the mines shut down it is probable that the gambusinos will bring in their hand-operated dry washers and concentrate the gravel around the workings. They may also discover small placer deposits in the adjacent arroyos; as the bedrock deposits are so small and scattered it is not probable that any large placer deposits will be found. 


\section{Hermosillo district}

Location and history

Scheelite was discovered in January 1943 in the Hermosillo district along the intrusive contact between granite and limestone at the edge of Villa seris, the small town directly across the Sonora River and a kilometer south of Hermosillo (p1. 40). In the period of active prospecting that followed the discovery, other tungsten deposits were found south and west of Villa Seris and also at the eastern outskirts of Hermosillo. More than 45 claims were recorded during 1943. But of these, only 18 were on deposits containing more than a few tons of ore. During the year several mills were planned and construction begun on four, but only the 3-ton Marfa Iuisa mill was completed, and it operated for only a few months.

The deposits are in low hills at the edge of a pediment. All are within a radius of 11 kllometers from town, and are reached from Hermosillo by dirt roads.

The writer was able to examine all the deposits with an ultraviolet lamp before excavating began, and later as exploration and mining progressed. The plane-table maps which accompany the report were made in July 1943 and revised in December of that year.

\section{Production}

Sales of ore and concentrates from the Hermosillo district during 1943 amounted to about 2,800 units of $\mathrm{WO}_{3}$ from the Maria Iuisa, Tungsteno, Noche, Cuate, and Santa Eduviges mines. In addition, at the end of 1943 ore containing about 1,640 units of $\mathrm{WO}_{3}$ was stored on the mine dumps of the district, but, as most of it contained between 1.3 and 2.0 percent of $\mathrm{WO}_{3}$, it was not marketable under the conditions then obtaining.

\section{Mining and beneficiation}

Most of the ore of the district is easily broken and all drililing, as well as holsting, is done by hand. Some selective mining guided by an ultraviolet lamp is done, but no panning or dry-washing. The ground holds open easily to the depths mined so far and no timbering is required. All the workings are dry and probably no water will be encountered above the level of the Sonora River. An abundant supply of water for mining and milling purposes may be obtained from shallow wells along the banks of the river. The local supply of electric power is small and variable.

In 1943 a small plant was erected in Hermosillo to treat ore from the Marla Luisa mine. It had a capacity of about 3 tons per day, and consisted of two small ball mills, a screen, and a table. A product containing 20 percent of $\mathrm{WO}_{3}$ was obtalned, the low recovery being due to the high proportion of slimes made.

All ore and concentrates produced in the district during 1943 were sold to the Tungsteno Mexicano agency in Nogales, the 
only buyers of low-grade tungsten ore in the state, who accepted only ore contalning 2.0 percent or more of $\mathrm{WO}_{3}$. As the ore from most of the mines carried between 1.0 and 2.0 percent of $\mathrm{WO}_{3}$, much of it could not be sold.

Although most of the tactite ore bodies were found by the tracing of scheelite-bearing float to its source, no attempt has been made to locate deposits of placer scheelite. The soll mantle on the pediment surface adjacent to the deposits contains more scheelite than many of the placer deposits being worked in other districts, and possibly the shallow washes also hold some placer concentrations. As the individual tactite bodies are small and scattered, and the drainage pattern is complex, it is unlikely that any large placer accumulations w1Il be found. When the bedrock deposits are abandoned gambusinos will probably clean the loose scheelite-bearing debris near the deposits and also prospect the washes.

\section{Rocks}

The rocks of the Hermosillo district comprise a sequence of metamorphosed limestones and shales of Permlan (?) age which have been intruded by granite. Diabase dikes intrude the metamorphic rocks and the granite.

The rocks may be divided into three units. The lower unit, which crops out on Cerro Marta, was originally a shale and has been altered to thin-bedded hornfels containing a few small lenses of tactite at its contact with the granite. The middle unit consists of thick beds of coarse-grained recrystallized gray limestone containing very little hornfels. It is in contact with the granite for a distance of 6 kilometers south and west of Villa Seris, and is the host rock for most of the ore bodies. The apparent minimum thickness of this unit is 600 meters. The upper unit consists of hornfels with a few thin interbedded limestone layers. It forms the ridges of Cerro Tecorlpa and Cerro Lujan, and is well exposed in the area north of the Rancho de las víboras, where the Iimestone layers have been altered to tactite.

Most of the granite is medium-grained and light-colored and contains small amounts of biotite and hornblende. North of Hermosillo the granite is darker, due to a greater proportion of blotite. In several places near the edge of the intrusive, there are irregular stringers of pegmatite, a few of which contain small amounts of gray or white scheelite, some of it as euhedral crystals:

Dikes of dark-green diabase are found in all parts of the district, cutting all other rocks. In many places they have invaded the ore bodies.

\section{Structure}

The outline of the intrusive contact forms a crescent open toward the east (pl. 40), within which an area of granite outcrop 8 kllometers in diameter is enclosed by the metamorphic rocks. The dip of the contact ranges from vertical to $70^{\circ}$ toward the metamorphosed Ilmestone. Bedding in the limestone in most places dips paraliel to the contact. The strike of the contact is parallel to that of the bedding for short distances, 
then truncates it obliquely in such a manner that, as the contact is followed southwestward from Villa Seris to the Rancho de las víboras, beds progressively higher in the limestone section are found against the granite.

Faults of two ages were mapped. The earlier faults are nearly parallel, having strikes ranging from $\mathrm{N} .15^{\circ} \mathrm{W}$. to $\mathrm{N}$. $40^{\circ} \mathrm{W}$. and dips of from $80^{\circ} \mathrm{E}$. to vertical. Dikes of diabase ranging in width from a few decimeters to 15 meters were intruded along these older faults. Younger faults of various attitudes cut the dikes. One, between the Noche and cuate mines, has a horizontal displacement of more than 250 meters. The faults are not mineralized.

Ore deposits

Mineralogy.-The ore mineral, scheelite, occurs in tactite which consists of garnet, calcite, epidote, and quartz. In the deposits north of Hermosillo and near Villa Seris, epidote is the predominant gangue mineral. In the mines of Cerro Tecorlpa and Cerro Lujan the scheelite is in a matrix of quartz with minor amounts of garnet and epldote. The tactite of the Rancho de las Viboras area is mostly garnet with minor epidote and almost no quartz.

The ore of the mines of Cerro Tecoripa and Cerro Lujan is soft and does not crop out, whereas that in the other parts of the district is hard and resistant to erosion. This difference must be due mainly to the leaching out of pyrite, which was present in a much larger proportion in the unleached ore in the western part of the district. Pyrite is found in the outcrop at the Tungsteno mine, and pseudomorphs and casts of pyrite crystals occur in the ores of the other mines of that section, which all contain notable quantities of lron oxide and brown calcite.

A secondary reason for the softness of the ore in the western part of the district may be that most of the ore lenses have.a north trend, parallel or nearly parallel to the system of faults and diabase dikes. Along some of the ore lenses, as at the cuate and Noche mines, there has been brecciation by minor fault movement.

Ai least a little powellite is presen't in nearly all the scheelite-bearing tactite of the district, but no molybdenite has been noted. The scheelite from all the mines is white in ordinary light. The mineral fluoresces a brilliant blue-white in ultraviolet light and probably contains less than 0.1 percent of molybdenum. No cuprotungstite has been found, and the only copper stains occur as scattered specks in the ore at the Beatriz mine. Scheelite is the only mineral of value that occurs in the tactite, and no other metalliferous deposits are known in the district.

Size and shape of ore bodies. - The exploited ore bodies have roughly tabular shapes, averaging about half a meter wide and from 3 to 20 meters long. The depth of an individual ore body is at least equal to its strike length in nearly all cases and a few had depths of nearly three times their strike lengths. All but one of the ore bodies are within 4 meters of an intrusive contact between limestone and granite, and most of them have granite on one wall and limestone on the other. The 
scheelite at the Beatriz mine, however, is 250 meters from the nearest exposed granite, but granite may lie beneath the deposit at a shallower depth.

Apparently the mineralizing solutions penetrated a maximum of 4 meters outward from the contact, usualiy less, and traveled along the bedding planes in the limestone. Thus the longer tactite bodies were formed where the bedding intersects the intrusive contact at a very acute angle. Where the bedding is nearly normal to the contact, the ore bodies are only 3 or 4 meters long. No tactite was formed where the bedding and the contact are parallel.

Areas where tongues of granite have penetrated elther upward or laterally into the limestone for some distance from the main contact were especially favorable for ore deposition. Tongues of granite are especially prominent at the María Luisa, Maravilla, Cuate, and Tungsteno deposits, and at the Noche the exposed part of the ore-bearing limestone has been completely cut off from the main limestone mass. This association of ore and granite tongues probably is not mere coincidence and it may in some way be due to greater heating of the limestone. It is also possible that the tongues, which cooled and solidified. more rapidly than the main granite mass, may have given a greater rigidity to that part of the limestone in which they occur. Thus the readjustments during the later stage of cooling would shatter these areas and make channelways for solutions, while the more homogeneous masses of limestone would jield by flowage of the limestone without shattering.

\section{Ore reserves}

No reserves of measured ore can be calculated in the Hermosillo district because no systematic development work is done in the mines, and ore is removed as soon as it is found. The term "indicated ore" refers to ore that is exposed on one or two sides either by the workings or in the outcrop. The extent of the known ore bodies can be closely estimated, for they are all controlled by geologic structure and are of small size. Ore bodies that are not exposed at the surface may be discovered by additional underground work, but the only one found so, far was the small pegmatite body in the Noche workings. The small size of the ore bodies which could be expected makes it unlikely that a profitiable exploratory program could be uadertaken.

In the following table, tonnage figures for reserves of indicated ore are given in short tons, as tungsten ore is sold in short ton units in the United States, the nearest avallable market for the ores of this district.

Future of the district

At the end of 1943 only the María Iuisa, Noche, Cuate, and Tungsteno mines were producing. Three other properties were doing development work, and the remainder were idle. It seemed likely that all work would be discontinued in 1944, and that about 25,000 units of $\mathrm{WO}_{3}$ in indicated ore of 1 percent grade or higher would be left in the ground. 
Table 6.-Estimated reserves of indicated tungsten ore in the Hermosillo district

\begin{tabular}{|c|c|c|c|}
\hline Property & Short tons & $\begin{array}{c}\text { Percent } \\
\mathrm{WO}_{3}\end{array}$ & Units \\
\hline 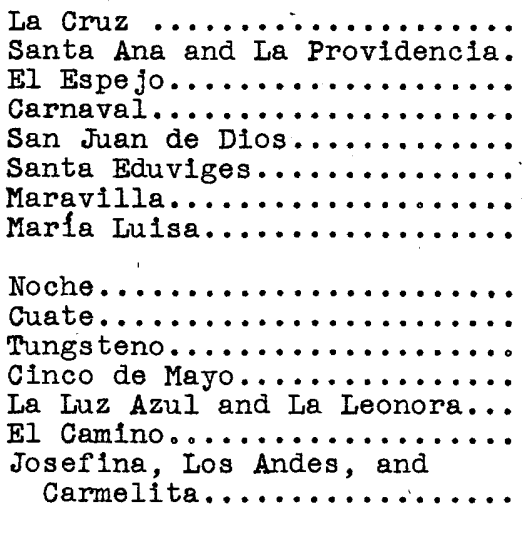 & $\begin{array}{r}150 \\
120 \\
160 \\
250 \\
1,000 \\
500 \\
500 \\
3,000 \\
1,500 \\
180 \\
1,200 \\
1,200 \\
1,200 \\
400 \\
1,200 \\
100 \\
12,660\end{array}$ & $\begin{array}{r}1.0 \\
1.0 \\
1.0 \\
1.0-2.0 \\
1.5 \\
1.5-2.0 \\
1.5-2.0 \\
3.0 \\
1.5-2.0 \\
1.7 \\
2.0-2.5 \\
1.5-2.0 \\
2.0-2.5 \\
1.0 \\
1.5 \\
1.0\end{array}$ & 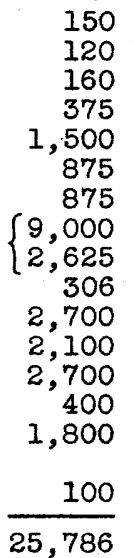 \\
\hline
\end{tabular}

Deposits at northeast edge of Hermosillo

La Cruz prospect. - The La Cruz claim covers a roof pendant of vertically dipping limestone completely surrounded by granite. The rock of the pendant is more resistant to erosion than the granite, and forms the top of a steep ridge at the northeastern outskirts of Hermosilio. Much of the limestone has been changed to garnet-epidote tactite, in which there are a few scattered scheelite crystals. The only concentration is in a layer of massive tactite half a meter wide and 10 meters long at the east end of the outcrop, which may contain 1.0 percent of $\mathrm{WO}_{3}$. The size and shape of the pendant suggest that it extends downward to a maximum depth of 10 meters: It probably contains 150 tons of mineralized rock containing 1 percent of $\mathrm{WO}_{3}$

Santa Ana and La Providencia prospects.-The Santa Ana and La Providencia prospects are in two small roof pendants of metamorphosed limestone adjoining the La Cruz claim. The scheelite-bearing rock is hard, massive quartz-epidote tactite which extends to only a shallow depth. A few pits have indicated a reserve of 120 tons of rock containing 1.0 percent of $\mathrm{WO}_{3}$.

El Espejo prospect.-The EI Espejo prospect is in a roof pendant of vertically dipping limestone about 40 meters long and 15 meters wide, surrounded by granite. It has one scheelite-bearing tactite layer half a meter wide and 15 meters long which probably extends to a depth of 8 meters and contains 160 tons of mineralized rock containing 1.0 percent of $\mathrm{WO}_{3}$. 
Deposits near Villa Seris

Beatriz mine.-The Beatriz mine (also known as Hercules or Argentina) is in limestone at the eastern edge of Villa Seris, at the foot of Cerro Marta. Bedding in the limestone strikes east and dips nearly vertically. One bed of gray recrystallized Iimestone a meter thick has, been partiy replaced for a strike length of 2 meters and to a depth of at least 15 meters by garnet, fine-grained quartz, coarse-grained brown calcite, a little pyrite, and epidote. Irregular crystals of honey-colored scheelite as much as 5 centimeters across occur in smell clusters and stringers in the replaced zone. Several years ago a vertical shaft was sunk on the mineralized zone to a depth of 15 meters in search of silver but scheelite was not recognized. The dump was hand-sorted in 1943 and yielded 3 tons of scheelite ore which contained about 35 units of $\mathrm{WO}_{3} \cdot$ No ore remains in place or in the dump.

Carnaval mine.-The Carnaval mine is on the main intrusive contact between limestone and granite on the pediment at the foot of Cerro Marta, just east of the highway to Guaymas. Scheelite-bearing tactite was formed where the contact cuts across the bedaing in the limestone (pl. 41). Individual tactite bodies are small and contain fine-grained scheelite in stringers 20-30 centimeters wide which parallel the bedding. The seven exposed lenses contain a reserve of 250 tons of indicated ore with from 1 to 2 percent of $\mathrm{WO}_{3}$. It is inferred that the lenses are 7 meters deep, twice the depth of the deepest working. The property was idle during the latter part of 1943.

San Juan de Dios mine. - The San Juan de Dios mine is west of the Carnaval claim at the south edge of Villa Seris. Seven short lenses of tactite crop out along the contact over a strike length of 150 meters (pl. 4l). The tactite is composed of about 50 percent of epidote and 50 percent of quartz, garnet, and scheelite. Scheelite occurs as subhedral crystals as much as 5 centimeters across, in stringers and disseminated in the tactite. If, as seems probable, each exposed body continues to a depth equal to its outcrop length, the prospect has a reserve of 1,000 tons of indicated ore. An assay of a composite sample of the dumps of the pits gave 1.5 percent of $\mathrm{WO}_{3}$.

\section{Deposits in Cerro Tecoripa and Cerro Lujan}

Santa Eduviges mine. -The Santa Eduviges mine (pl. 4l) is in seven lenses of tactite, two of them very small, on the intrusive contact at the north end of Cerro Tecoripa. The contact is here irregular, with tongues of granite in the limestone and several smali mineralized inclusions of limestone in the granite. Four diabase dikes follow the planes of preexisting faults. Two of the dikes bound the main ore body, which lies along the south edge of a wedge-shaped fault block of limestone. A few euhedral crystals of gray scheelite occur in an irregular vein of quartz and muscovite, too small to be shown on the map, in an outcrop of granite about 10 meters south of the adit portal.

The largest ore body has been opened to a depth of 9 meters by means of an adit; three of the other tactite lenses have been opened to depths of 3 meters by means of two pits and two shallow shafts. Should the main ore body extend to a depth of 12 meters and the other ore bodies to depths of 5 meters each, 
reserves of indicated ore would be 500 tons containing 1.5 to 2.0 percent of $\mathrm{WO}_{3}$. Work was stopped in september 1943, after 50 tons of hand-sorted ore containing 2.5 percent of $\mathrm{WO}_{3}$ had been accumulated from all the workings.

Maravilla mine.-The Maravilla claim covers the intrusive contact for 500 meters along the steep east slope of Cerro Tecoripa. Except for two small tactite lenses which probably contain less than 5 tons each, all the ore bodies are at the south ond of the claim (pl. 41). Here the contact is very irregular and several narrow granite tongues extend into the limestone, confining the ore bodies to short strike lengths and possibly cutting them off at depth. Two shafts, sunk on separate ore bodies, were still in ore at a depth of 6 meters. Another working (the Mica shaft), 3 meters deep, cut a small body of muscovite-rich scheelite-bearling pegmatite which contained about 2 percent of $\mathrm{WO}_{3}$. However, the pegmatite extended only to a depth of 3 meters. If the two tactite ore bodies exposed in the 6-meter. shafts extend to depths of 10 meters, the two together contain 400 tons of ore. The total reserves of indicated ore contained in all the ore bodies are 500 tons containing an average of about 1.5 to 2.0 percent of $\mathrm{WO}_{3}$.

Marfa Luisa mine.-The Marfa Luisa claim is at the south end of Cerro Tecoripa, and includes at least 15 scheolite-bearing tactite lenses which crop out along the contact. Only the tactite at the south end of the claim has been worked. Here four shafts have been sunk to depths of 15 to 20 meters and some stoping has been done (pl. 42). The three largest ore bodies replace favorable beds in the limestone and are arranged en echelon. The north ore body is cut by a diabase dike 1 to 2 meters thick, intruded along a fault of 2 meters horizontal displacement.

Original1y the scheelite was in a gangue of quartz, calcite, garnet and epidote, with abundant pyrite. The pyrite has all been oxidized, and much of the calcite, garnet, and epidote have been weathered out, leaving a porous, partly brecciated ore composed of quartz, scheelite, soft iron oxide, and finegrained brown calcite. There probably has been a decrease in volume of about half in the upper part of the vein, and as no scheelite has been removed the tungsten content is now 6 percent $\mathrm{WO}_{3}$ at the surface, gradually decreasing to around 3 percent at a depth of 20 meters, and even at this depth there has been some increase in grade. No unoxidized sulfides have been found at the Marla Luisa, although pyrite is found in the outcrops on the El Tungsteno claim, only a short distance away. The Marla Luisa workings are dry, al though several water-worn caves in the Iimestone underground indicate that the circulation of ground water was once vigorous. No supergene scheelite. was noted, and most of the scheelite crystals are hard and. unaltered.

The reserves of indicated ore above the 30-meter level in the tactite bodies at the south end of the claim are 3,000 tons containing 3 percent of $\mathrm{WO}_{3}$. The ore bodies at the north end of the claim (not shown on pl. 42) probably contain 1,500 tons of inferred ore with from 1.5 to 2.0 percent of $\mathrm{WO}_{3}$ to a depth of from 5 to 10 meters. North of the workings, other ore bodles may be discovered at greater depths.

Noche mine.-The Noche mine is in the pass between Cerro Tecoripa and Cerro Lujan. Scheelite-bearing tactite has been found at the eastern edge of a small block of limestone which is separated from the main Iimestone mass by a tongue of 
fine-grained granite 5 meters wide (pl. 42). Two parallel diabase dikes which intrude the ore body do not crop out, but are well exposed in a crosscut on the 7 -meter level.

The crosscut exposed a small body of granite pegmatite, about 2 meters in diameter, almost entireiy enclosed within the limestone and apparently connected with the granite only by a stringer of pegmatitic granite 25 centimeters wide leading upward. The granite pegmatite body was composed of coarsegrained quartz, feldspar, and greenish muscovite, and contained 5 to 10 percent of scheelite in coarse subhedral crystals as much as 8 centimeters across.

The main tactite body dips west and probably does not continue downward for more than 10 meters below the 7 -meter level. Reserves of Indicated ore to a depth of 17 meters are 180 tons containing 1.7 percent of $\mathrm{WO}_{3}$. Fifty tons of ore which assayed 1.9 percent of $\mathrm{WO}_{3}$ was produced from the property.

Cuate mine.-The Cuate claim is at the north end of the Cerro Lujan, and covers several lenses of scheelite-bearing tactite along the intrusive contact ( $\mathrm{pl}$. 42). The main ore body, developed by a shaft 16 meters deep, shows a spotty scheelite mineralization. At the surface the ore body is 20 meters long and 3 meters wide from wall to wall, but this width includes that of an intruded diabese dike. The segment of the ore body east of the dike pinches out at a depth of 5 meters.

Another shaft, 60 meters north of the main shaft, intersected an east-dipping fault and encountered granite at a depth of 5 meters; a crosscut driven into. the footwall from the bottom of this shaft was entirely in granite. The fault and the intrusive contact intersect at the surface 15 meters farther north. Thus it appears that the ore bodies lie along the east. side of a wedge-shaped fault block of limestone, and are cut off at depth at the south-pitching intersection of the fault and the contact. A crosscut into the footwall to the contact may neveal the faulted segments of the ore bodies.

Several small lenses of tactite near the south end of the claim contain some powellite, but little scheelite. The Cuate claim has reserves of about 1,200 tons of indicated ore containing 2.0 to 2.5 percent of $\mathrm{WO}_{3}$ above the projected position of the fault. The 50 tons of sorted ore shipped from the property in 1943 assayed 3.5 percent of $\mathrm{WO}_{3}$.

Tungsteno mine.-The workings of the El Tungsteno inine.lie in an embayment of the intrusive contact at the edge of the pediment on the east side of Cerro Lujan (pl. 42). There are nine shallow shafts and six pits, each on separate small lenses of scheelite-bearing tactite. Most of these workings are shown on plate 42. Four lenses pinched out at a depth of 9 meters, and the others were even shallower. The tactite was formed in beds of coarse-grained recrystallized limestone favorable for replacement, and, as the contact truncates the bedding at an obtuse angle, the ore bodies are of small lateral extent. At the southwest corner of the mapped area a few stringers of pegmatite containing a little scheelite adjoin the ore bodies.

Reserves of indicated ore on the Tungsteno claim above the level of the deepest working are 1,200 tons containing 1.5 to 2.0 percent of $\mathrm{WO}_{3}$. Shipments to the end of 1943 were about 250 tons of screened ore with an average content of 2.3 percent of $\mathrm{WO}_{3}$. 
Cinco de Mayo mine. - The cinco de Mayo claim is on the intrusive contact along the southeast end of Cerro Iujan. Six short lenses of tactite have been discovered, all on projections of limestone which jut out into the granite (pl. 43). The tactite is composed principally of garnet with lesser amounts of scheelite, calcite, epidote and quartz; some secondary iron oxides and powellite accompany the scheelite. Several small kidney-shaped masses of nearly pure scheelite were found at about the 8-meter level in the shaft at the north end of the mapped area, lying exactly on the contact between granite and tactite. The largest of these masses weighed about 6 kilograms and was coated with muscovite.

The workings consist of one shaft 23 meters deep at the north end of the claim, three shafts of from 4 to 15 meters 1 depth, and several prospect pits. The 23-meter shaft, which is inclined toward the east, penetrated the granite at 10 meters' depth. It is reported that no ore was found in a crosscut driven to the contact on the 23-meter level. The average depth of the outcropping ore bodies was about 7 meters, in all cases at least equal to their strike length. Total reserves of indicated ore in the six lenses are 1,200 tons containing from 2.0 to 2.5 percent of $\mathrm{WO}_{3}$. Nearly 300 tons of ore reported to contain 2.75 percent of $\mathrm{WO}_{3}$ had been extracted by the end of 1943 and was stored on the dumps.

\section{Deposits near Rancho de las Víboras}

Ia Luz Azul and La Leonora prospects. -The Ia Luz Azul and the La Leonora prospects are along the granite contact just west of the highway to Guaymas, about 10 kilometers south of Hermosillo. Scheelite occurs in lenses of massive garnet-epidote tactite against the granite. Separate ore bodies on these claims have been opened by means of five shallow shafts. Reserves of indicated ore are.400 tons containing about 1.0 percent of $\mathrm{WO}_{3}$.

El Camino mine. - The El Camino claim covers a block of limestone 200 meters long, with a maximum width of 70 meters. The south side of the block is in fault contact with the granite, but the irregular contact on the other sides is intrusive, and several bodies of tactite have been formed at this contact (p1. 43). Most of the tactite bodies are composed of nearly barren garnet, but two of them, one 20 meters long and the other 25 meters long, contain about 1.5 percent of WO 3 . The width of the ore bodies ranges from a few decimeters to 2 meters. Total reserves of indicated ore to a depth of 10 meters are 1,200 tons containing 1.5 percent of $\mathrm{WO}_{3}$. No ore has been shipped from this property and no new work is planned. The scheelite-bearing tactite is hard and unaltered and the ore cannot be raised to shipping grade by screening alone.

Josefina, Los Andes, and Carmelita prospects.-The Josefina, Los Andes, and Carmelita claims extend along the contact between granite and limestone for 4 kilometers southeast of the El Camino prospect (pl. 40). A few small lenses of scheelitebearing tactite have been discovered. Total reserves of indicated ore on all four claims are less than 100 tons containing 1.0 percent of $\mathrm{WO}_{3}$. The sedimentary rocks àlong this part of the contact are not favorable for replacement, as most of the beds belong to the upper hornfels member of the limestone series, and the bedding dips at low angles away from a steeply dipping contact. 


\section{Deposits north of Hermosillo}

In the region around Agua Salada, about 35 kilometers north of Hermosillo (pl. 39), four tungsten claims were recorded during 1943. These were not visited and it is not known whether any tungsten has been produced from them. Outcrops of tactite containing sparsely disseminated scheelite were found on both sides of the highway between Nogales and Hermosillo, about 50 kilometers north of Hermosillo. Additional prospecting of the intrusive contacts in this region may disclose some minable ore bodies.

\section{Deposits northeast of Hermosillo}

El Saturno mine.-In 1942 Pedro J. Fruns and Frank Fast produced 164 units of WO $_{3}$ from a small scheelite-bearing tactite body near Pozo de Toyos, about 22 kllometers northeast of Hermosilio (pl. 39). The mine, known as the El Saturno, is at the edge of a body of silicated and silicified limestone, near a contact with altered andesite or diorite. Scheelite occurs as stringers in the metamorphosed limestone associated with pyrite, chalcopyrite, and quartz. No ore remalns in sight on the property.

Picacho district.-Tungsten-bearing tactite was discovered in 1943 at the east side of El Plcacho, an isolated peak at the edge of the dirt road between Ures and Hermosillo, about 25 kilometers northeast of Hermosillo and 4 kilometers north of Pozo de Toyos (pl. 39). Three claims were recorded, the El Nublado, El Picacho, and La Florencla. Only a little work was done at these claims in the fall of 1943, and no ore was mined.

The El Nublado prospect is in a northwest-striking belt of discontinuous tactite outcrops surrounded by metamorphosed limestone and hornfels (pl. 44). The limestone is probably underlain by granite which intrudes all the other rocks of the district. An outcrop of granite, 200 meters west of the limestone, is separated from it by an area of silicified volcanic breccia which is in contact with the limestone along a preintrusive fault.

The tactite, representing the more easily replaced beds in: the Iimestone series, consists of epidote and gamet with. smaller amounts of scheelite, powellite, and oxidized copper minerals, The scheelite is disseminated in the tactite and only in two lenses is there a sufficient concentration to be considered as ore. About 300 tons of indicated ore, with 2 percent of $\mathrm{WO}_{3}$, and 1 , 000 tons contalning 1 percent of $\mathrm{WO}_{3}$ may be estimated to depths of 10 meters from exposures in the one shallow pit and at the outcrops. The tactite is very hard and dense and is difficult to work by hand methods. .

The El Picacho and La Florencla claims are adjacent to the El Nublado claim, on the continuation of the belt of tactite outcrops for 400 meters to the south. Discontinuous tactite lenses similar to those on the El Nublado claim carry small amounts of scheelite and oxidized copper minerals, but no ore reserves, are indicated by the outcrops or by the old pits put down in the past in search of silver and copper. Exploration work was begun the first of 1944 but discontinued shortly thereafter. 


\section{Zubiate district}

Granate prospect. -The Granate claim, located in 1943, covered part of a poorly exposed contact between limestone and granite about 30 kilometers east of Hermosillo and about 8 kilometers southwest of Las Norias, just west of the road between Las Norias and Zubiate ( 1.39 ). Some scheellte was found as float along the contact, but none was found in place and the prospect was abandoned.

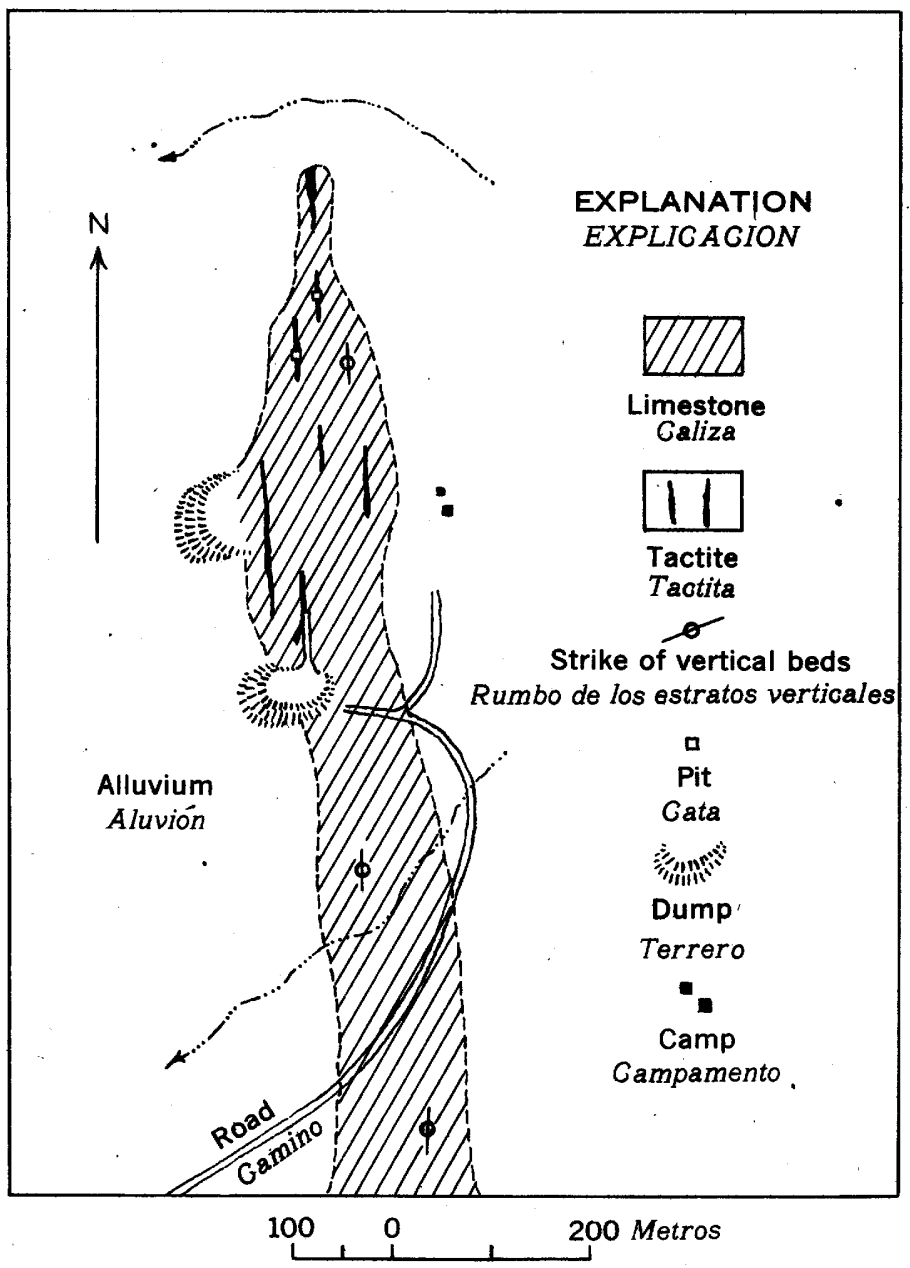

Figure 15.-Geologic map of the Virgen de Guadalupe mine, Guaymes district.

Guaymas district

The Virgen de Guadalupe is the only tungsten deposit that has been discovered in the Guaymas district. Granite crops 
out in several places northeast of Guaymas and there is a good chance that other deposits in or near those areas may be discovered as a result of prospecting.

Virgen de Guadalupe mine. - The Virgen de Guadalupe mine is about 6 kilometers east of Rancho Nochebuena and 25 kilometers north of Guaymas. It lies about 4 kilometers east of the highway between Hermosillo and Guaymas, and is accessible from it by 9 kilometers of dirt road.

The copper-stalned outcrops of tactite were prospected years ago for copper and silver, but probably no ore was shipped. The old workings were re-denounced by Fernando Navarro and Pablo Ramirez in June 1943 when scheelite was found in one of the dumps. Seven small lenses of scheelite-bearing tactite were outlined by subsequent prospecting (fig. 15).. Development work continued to the end of 1943, but attempts to mine the hard, dense tactite by hand methods proved unsúccessful. Twelve tons of ore containing 10 percent $\mathrm{WO}_{3}$ and 85 tons containing 1.5 percent $\mathrm{WO}_{3}$ was taken out.

Outcrops of tactite lenses in vertically dipping limestone, altered by contact metamorphism, form a low strike ridge completely surrounded by alluvium which rises above the smooth slope of the western flank of the Nochebuena Range. There are no other outcrops of limestone nearby, nor is any intrusive rock exposed. The adjacent range is composed of basalt. flows.

Garnet, epidote, calcite, and quartz make up the tactite, which contains secondary oxides of copper and iron as well as disseminated crystals of scheelite. The known ore bodies contain about 1,000 tons of ore containing $1.0-1.5$ percent of $\mathrm{WO}_{3}$ to a depth of 10 meters, the depth of the deepest working. It is not unlikely that granite will be reached at this depth beneath the intensely metamorphosed tactite at the north end of the outcrop, although the tactite at the south end may continue to several times this depth.

\section{Deposits north of Tónichi}

Tecolote prospect.-Early in 1943 Martiniano Encinas of Tónichi found a little scheolite in contact-metamorphosed lime stone on the Tecolote Ranch, about 20 kllometers northeast of Tónichl, just east of the truck road to Bacanora. No minable ore bodies were discovered, however, and the property was abandoned in the fall of that jear.

Extensión de Uranio prospect.-The Extensión de Uranio prospect is at Bajlo de Los Rastritos, about 10 kilometers southeast of Bacanora, and may be reached from there on horseback in 5 hours. It is owned by Harry A. Pitts of Bacanora who reports that a spectrogram of a green mineral (hornblende) from the outcrop showed the presence of uranium. He has been unable to confirm this occurrence by subsequent analyses. Scheelite and cuprotungstite occur sparsely disseminated in a small pegmatite dike, and other traces of scheelite have been found in an outcrop of tactite nearby.

Cadena de Cobre prospect.-Homer L. Carr reported that in 1943 he discovered scheelite on his copper claim, the Cadena de Cobre, located about 14 kilometers north of Sahuaripa on the south bank of the Yaqui River. Fine-grained scheelite occurs in tactite along an intrusive contact between limestone and 
granite. The copper mineralization is in a separate part of the contact zone which carries no tungsten. Selected samples of the best ore contained as much as 3.75 percent of $\mathrm{WO}_{3}$, but the whole mineralized zone contains considerably less than this. The known mineralized body is about 50 meters long and is reported to range up to several meters in width.

Coker prospect.-James E. Coker of Soyopa reports that in the spring of 1943 he discovered scheelite at El Saucito and Chlquiquelite, about 4 kilometers west of the Yaqui River and 34 kilometers north of soyopa. The prospect may be reached by traveling on horseback from Soyopa.

Scheelite occurs in discontinuous bodies of tactite for a distance of several hundred meters along a contact between granite and limestone. The scheelite is medium- to fine-grained and erratically distributed in the tactite lenses, some of which probably contain as much as 2.0 percent of $\mathrm{WO}_{3}$. Exploration work was carried on during the fall of 1943 and the first few months of 1944 , then discontinued. It is not known if the adjacent washes were prospected for placer deposits.

\section{PEGMATITE' DEPOSITS}

Most of the production of tungsten from the southern part of Sonora has come from pegmatite deposits; however, the known deposits of this type are almost worked out and the reserves are of low grade.

The principal deposits are east of the Yaqui River in the districts of San Nicolás, Santa Ana, Santa Rosa, and El Encinal; others are along the Yaqui at La Dura and Nacimiento. Coarse placer scheelite in the river gravels north of La Dura suggests that still other deposits may be discovered in that region.

Scheelite is found in steeply dipping pegmatite dikes or segregations at the top or sides of the intrusive bodies of granite. Most of these dikes are within 75 meters of the enclosing quartzite or andesite, but only a few thin stringers extend into the surrounding rock. Possibly this is because the invaded rock in most cases is massive quartzite. At san Nicolás, the quartzite roof of the intrusive has been removed. by erosion, but the contact, as projected from exposures on nearby hilis, would pass less than 100 meters above the outcrop of the dike.

In general, the pegmatites are harder than the surrounding granite and stand out above the surface of the ground as low ridges. The dike at the La Cruz mine forms the backbone of a steop ridge which rises high above the more subdued topography of the surrounding granite hills.

\section{Mineralogy}

The mineralogy of the pegmatite dikes is simple. The predominant gangue minerals are quartz and orthoclase feldspar, with varying amounts of muscovite, chlorite, hornblende, epidote, magnetite, sphene, and pyrite. Chalcopyrite is prominent in the ore of the La Cruz mine, and molybdenite and its alteration product, powelifte, are present in nearly all the dikes. 
Scheelite occurs as irregular anhedral crystals except where it lines vugs, where it has the common pyramidal form. Its color is white, grayish or jellowish, or a shade of green. The green color is due to the replacement of the calcium of the scheelite by copper to form cuprotungstite. Partial replacement along and outward from cleavage planes of the scheelite is responsible for the lighter green color; more nearly complete replacement results in the darker green crystals, some of which are almost wholly composed of cuprotungstite.

In ultraviolet light much of the scheelite has a yellowish tinge, showing that it contains a small amount of molybdenum, generally less than 1 percent.

\section{Mining}

In the past the pegmatite dikes themselves were mined, but in the years since 1935 the old mine dumps and placer gravels derived from the dikes have been worked and have furnished most of the ore produced. A little underground work is being carried on in a random manner at the La Cruz and San Julián mines. In other places high-grade pockets in the outcrops of the dikes are gouged out by hand methods and concentrated in dry washers. In some districts ultraviolet lamps are used to find the highgrade spots, but most of the work still is guided by panning.

The placer deposits and the dumps of the old mines are worked by small portable dry washers each operated by one or two men. Only the material which passes a screen of about I centimeter mesh is worked, although the operator watches all the oversize as the material is being screened to find nuggets. In ground containing about 0.5 percent of $\mathrm{WO}_{3}$, one man can take out about 1 to 1.5 kllograms of concentrates per day by this method. The concentrate is usually cleaned by panning if water is avaliable nearby, as cleaned concentrates bring a higher price.

\section{San Nicolás district}

La Cruz mine. - The La Cruz mine, a pegmatite dike as much, as 8 meters wide and 150 meters long, crops out at the crest of i steep ridge I kilometer southeast of the town of San Nicolás. The nearest water supply is in the small stream that flows through the town at an elevation of 200 meters below the mine workings .

The property was denounced 7/ as a copper deposit in 1910 by. John H. King. He sold it later to the Phelps Dodge interests, who operated it during World War $I$, and are reported to have taken out about 1,000 tons of tungsten concentrates, a large proportion of which was hauled by mules to Nacozari. Frank Fast operated the mine from 1929 to 1935 , extracting more than 200 tons of concentrates. Emilio Bouvet of Navajoa bought the property in 1935 and set up an agency to purchase concentrates from the gambusinos who were then working the deposit. In 1943 he sold the mine to the Socledad Financiera of Mexico city, which continued to purchase concentrates from the gambusinos during that year.. In April 1943, about 150 men were 
operating 75 dry washers on the dump meterial, extracting about 5 short tons of 50-percent $W_{3}$ concentrates per month, and selling the concentrates to the local buyer for 3.25 to 3.50 pesos per kilogram.

Scheelite, which is associated with chalcopyrite, molybdenite, chlorite, and pyrite in the dikes, is concentrated in pods and stringers. Because much of the scheelite is partly altered to cuprotungstite, the concentrates have a high copper content which lowers their value. Molybdenum is also present in the scheelite, but in unimportant amounts. It is reported that one pocket of 20 tons of nearly pure scheelite was found; another contained 4 tons.

An adit 50 meters long driven into the east side of the hill intersects the dike at a point 50 meters below the outcrop. From the adit, drifts follow the dike to the northeast and southwest. The northeast drift is 10 meters long; that to the southwest is accessible for 30 meters, beyond which it and extensive stopes above it are caved. In 1943, gambusinos were drawing from the caved stopes some of the dike rock whlch, according to several assays, contains about 0.7 percent of $\mathrm{WO}_{3}$. As the caved material is drawn out the surface of the ground above it settles.

A little scheelite may be seen in the drift and there are a few pods at the edges of the accessible stopes, but in neither place is there an appreciable tonnage of ore. It is reported that no ore was found in the workings below the adit level and that these workings are now filled. If so, the mine is worked out, as all the dike above the adit level has been explored.

Gambusinos concentrating and reconcentrating the material. of the old dump have spread it out as an uneven layer up to a meter or two thick on the slope below. This material, according to several assays, contains from 0.2 to 0.5 percent of WO3 and can be worked only by small-scale dry placer methods.

El Búfalo mine.-The El Búfalo mine, owned by Ygnacio Garcia of San Nicolás, is on a steep hiliside near the head of the Arroyo del Aguajito, about 1 kilometer southwest of San Nicolás. The property was denounced in 1934, and 2 tons of concentrates was produced that year, mainly from small placers on the billside below the mine and in the adjacent arroyo. In 1942 and 1943,2 tons of concentrate was produced from handsorted high-grade ore which was treated in the owner's arrastre.

Scheelite occurs in irregular stringers and pods of quartz and as thin coatings on joint planes of the granite. The veinlets are probably of pegmatite origin, and also contain small amounts of pyrite and chalcopyrite. Nearly all the scheelite is white and free of molybdenum and copper, but some contains a little cuprotungstite. The stringers, each generaliy less than a meter long and 10 centimeters wide, are arranged with no systematic orientation in a zone of mineralization at least 20 meters square on the surface. This zone has been exposed to a depth of 10 meters by an open cut. However, the adjacent hillside is covered by colluvium, and the size of the mineralized block may be larger than is now known.

One large open cut and two smaller ones have jlelded about 500 tons of scheelite-bearing rock which probably contained around 0.5 percent of $\mathrm{WO}_{3}$. Within 5 meters of the workings there are 1,000 tons of mineralized rock that may contain an average of 0.5 percent of $\mathrm{WO}_{3}$. . This material would be classed 
as indicated ore if the content of WO 3 were higher. It is possible that there may be a larger tonnage of this material but exposures at the time of the examination were insufficient for a closer estimate. The granite is hard and unaltered, and the scheelite in the included veinlets can be separated from it only with difficulty by the hand methods in use at the deposit.

San Julián mine.-The San Julián mine, also known as the San Carlos and the Puerto de Buenavista, is 1 kilometer north of the town of Santa Ana and about 10 kilometers south of San Nicolás beside the trail that connects the two towns. The nearest source of water is the small creek at Santa Ana, about 150 meters lower. Scheelite occurs in a zone of stringers and pods of pegmatite in granite. This mineralized zone, which is 5 meters wide and 30 meters long, is about 50 meters down the slope of the hill from the contact between granite and quartzite. The stringers are small, averaging from 10 to 20 centimeters across, and less than a meter in length. The whole mineralized zone has been decomposed by weathering and the scheelite can be partially separated from the rock by screening.

The workings consist of irregular shallow open cuts and small burrowlike openings along the seams of high-grade material. In March 1943, 6 men were gouging out the high-grade pockets in the workings and 30 other's reworking the dump material and the placer gravel in the arroyo below the mine with dry washers produced about $40 \mathrm{kilograms}$ of 50 -percent $\mathrm{WO}_{3}$ concentrates per day. As the scheelite is white and contains very little molybdenum, it sells for a higher price than the concentrates from the La Cruz mine.

It is difficult to estimate the reserves of the property because many of the workings are caved and much of the surfage adjacent to the mine is covered. The pillars in the block which was being mined in March 1943 contained about 500 tons of mineralized rock. A small amount of development work might prove the presence of a few thousand tons of mineralized rock containing an average of about 0.5 percent of WO 3 within 10 meters of the workings. The dump material and the placer gravels contain less than 0.3 percent of $\mathrm{WO}_{3}$.

\section{Other properties in the San Nicolás district.-Scheelite} has been reported occurring with molybdenite at the La Mexicana, Galaviz, and General Obregon mines near Santa Ana and at the Tres Piedras mine near Santa Rosa. In addition, gambusinos work small scheelite placers throughout the district, furnishing a small but fairly constant production. All the known occurrences are probably of the pegmatite type, and it is unlikely that production from them could be increased markedly.

\section{El Encinal district}

El Encinal is a small town about 30 kilometers east of Tónichi, situated in a small summit valley on the drainage divide between the Sahuaripa River and the Yaqui River. It is most readily reached from Tónichi, by a two-day trip on horseback over a trail which climbs from an altitude of 180 meters at Tónichi to 1,000 meters at El Encinal.

Small amounts of molybdenum concentrates have been produced from the mines and prospects of the district since the first World War. In 1934 scheelite was discovered in the old mine workings and in other places nearby, and forty claims were 
located within a few months, but nearly all soon were abandoned. There are two mines in the district, the Lydia and the Veta Rey, and a score of prospects.

The town of El Enclnal is near the center of a nearly circular outcrop of granite about 2 kilometers across, surrounded by a rim of hills of volcanic rocks. At the western $\theta$ dge, the granite is faulted against the volcanic rocks, but on the other sides the granite apparentiy is intrusive into the volcanic rocks. The granite is the marginal phase of the underlying batholith and has a wide range of texture and composition. In the eastern half of the area, especially along the contacts between different facies of the granite, there are many small pegmatite dikes and lenses containing scheelite, molybdenite, and a little pyrite and chalcopyrite.

Lydia mine.-The Iydia mine is $1 \mathrm{kilometer} \mathrm{southeast} \mathrm{of}$ El Encinal, only a few hundred meters inside the margin of the intrusive. It is owned by the Compañla Minera de Sonora, S. A., which is reported to have produced 170 tons of hand-sorted ore containing 30 percent $\mathrm{MOS}_{2}$ and 35 tons containing 10 percent MoS $_{2}$. No scheelite has been produced, and the mine has been idle for several years.

The Lydia "vein" is a zone of tabular lenses of pegmatite in granite. Individual lenses are a few meters long and less than a meter thick, and form a northeast-trending zone 30 meters long and up to 2 meters across. The zone has been followed to a depth of 20 meters by an inclined shaft which is intersected by an adit on the lo-meter level. Molybdenite is present throughout the zone, but scheelite was found only between the 5-meter and 15-meter levels in the shaft and for a distance of 15 meters along the drift.

The known pockets of molybdenite ore have all been removed, and none of the scheelite stringers is large anough to be mined except by gambusino methods.

Veta Rey mine.-The Veta Rey mine is about 700 meters northeast of El Encinal. It is owned by Francisco othon, of El Encinal, who, in March 1943, had a crew of three men taking out tungsten ore from the underground workings and from a few shallow cuts on the surface. The ore is mined selectively with the aid of an ultraviolet lamp, crushed by.hand, and concentrated by panning. The molybdenit $\theta$ in the pan is floated out by adding a spoonful of lard to each pan of mixed concentrates.

The Veta Rey "veln" is an irregular tabular zone of lenses and stringers of fine-grained pegmatite in granite. The zone is. 50 meters long and has a maximum width of 2 meters. Crystals of scheelite, molybdenite, pyrite, $\dot{a}$ nd a little chalcopyrite occur as smail scattered clusters in the pegmatite. The vein zone as a whole contains less than about 0.5 percent of $\mathrm{WO}_{3}$ and 2 percent $\mathrm{MoS}_{2}$.

'Two inclined shafts have been sunk' on the zone to a depth of 10 meters and are connected at their bases by a drift 20 meters long. A crosscut adit 20 meters long reaches the drift from the side of the hill. All the ore above the drift level has been stoped, and two short winzes put down in the floor of the drift found only very lean ore.

Other properties in the El Encinal district.-Between the town of El Encinal and the Lydia mine are a dozen or so small surface workings in discontinuous pegmatite lenses. All the 
exposed lenses are less than 10 meters long and half a meter wide; most are less than 10 centimeters wide. Scheelite is sparsely disseminated in the lenses, but nowhere is it abundant enough to be exploited.

\section{La Dura district}

A few kilometers east of La Dura is a small body of granite intruded into quartzite. Quartzite outliers also cap several of the low hills within the granite area, suggesting that the exposed granite is very near the roof of the intrusive. Discontinuous dikes and irregular masses of scheelite-bearing pegmatite occur at several places in the granite. The small tungsten production of the district has come mainly from placer deposits, and only a few shallow pits have explored the bedrock deposits, which are of low grade. There is no water nearer than the Yaqui River about 5 kilometers away, and all work is done by gambusinos using portable dry washers. The two principal properties are the EI Tungsteno and the La Libertad. Total production of the district to May 1943 is estimated at 30 tons of concentrates containing 55 percent of $\mathrm{WO}_{3} \cdot$

El Tungsteno claim.-The El Tungsteno claim is about $5 \mathrm{kil}-$ ometers from La Dura, on the east side of the road to Ciudad obregón. Three discontinuous parallel pegmatite dikes strike north and form low steep-sided ridges separated by narrow gravel-floored washes. At the west side of the claim, quartzite caps a mesa only a few meters higher than the mineralized dikes (fig. 16).

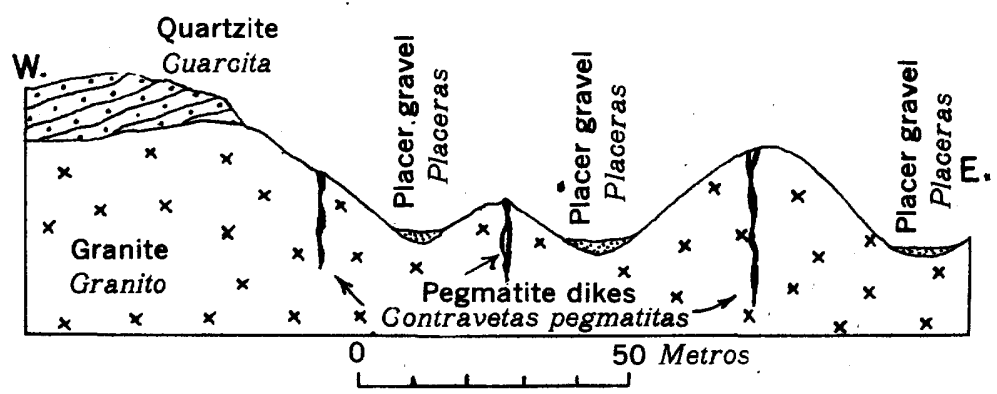

Figure 16. -Geologic section through El Tungsteno claim, La. Dura.

The minerals of the pegmatite include feldspar, quartz, epidote, amphibole, muscovite, scheelite, and magnetite, all medium-grained. Numerous vugs are lined with intergrown coarse crystals of quartz, feldspar, and scheelite. The scheelite is blue white in ultraviolet light and cream-colored in ordinary light.

Some scheelite is present in the soil mantle on the hillsides below the outcrops and scattered through the gravel of the arroyos, but the richest concentration is in a thin lajer a few centimeters thick just above bedrock at the bottom of the gravel. The gravel is as much as 2 meters thick in the middle of the channel, and the scheelite-bearing layer is mined by "means of small untimbered burrows, just large enough for a man 
to crawl through, along the bedrock surface. Nearly all the high-grade material had been removed by this method by April 1943, when a few gambusinos were then dry-washing the upper gravels and others were gouging out the richer pockets in the outcrops. The lenses of pegmatite rock are so small and discontinuous that they could not be mined profitably on a large scale.

La Libertad claim.-The La Libertad claim adjoins the western edge of the El Tungsteno claim, and lies mostly west of the road to Cludad obregón. Four short pegmatite dikes with spotty scheelite mineralization have been prospected by means of seven shallow pits, but little ore was found. Gambusinos worked the soll mantle on the slopes adjacent to the prospect pits and the gravel of the shallow nearby washes. The property was examined with an ultraviolet lamp and very little scheelite was seen on the surface or in the workings.

Other prospects in the La Dura district.-At the San Marcial and the La Zolla prospects Just south of the El Tungsteno claim small amounts of scheelite are said to have been mined from scattered placer deposits, but no economically workable bedrock deposits have been found. The district has been prospected rather thoroughly and although some smaller placer deposits may be found from time to time, it is unlikely that any of them will be larger than the deposits already known.

\section{Nacimiento district}

Nacimiento is a station on the railroad between Corral and Tónichi, about $15 \mathrm{kllometers} \mathrm{south} \mathrm{of} \mathrm{La} \mathrm{Dura} \mathrm{and} 150 \mathrm{k} 110-$ meters southeast of Hermosillo. It is accessible only by the railroad or by horseback, as the automobile road between La Dura and Cludad Obregón passes 15 kilometers to the east, on the other side of a mountain range.

The station is near the center of a northwest-trending area of granite about $5 \mathrm{kilometers}$ wide and 15 kilometers long. The granite, which intrudes quartzite and andesite, weathers more rapidiy than those rocks. As a result, erosion has carved from the granite a basin-shaped valley, surrounded by rugged hills, which is bisected by the Yaqui River. Scheelite is found in some of the pegmatite dikes and stringers in the granite, as well as in the placer gravels derived from them. The distribution of miost of the dikes is irregular; they trend in many directions. Most are only a few meters long and less than half a meter wide.

Deposits near Nacimiento.-About a ton of tungsten concentrates was mined in 1943 from a dike and the adjacent placer gravel I kilometer west of Nacimiento. A few flakes of molybdenite occur with the scheelite. Most of the ore production was from the placer gravels.

Small scheelite-bearing stringers were discovered on the east bank of the river in May 1943. The shallow placer deposits yielded only about a hundred kilograms.

The recent gravel bars on both sides of the channel of the Yaqui River from Nacimiento downstream for several kilometers are known to contain gold and scheelite, and they have been worked intermittently by gambusinos for many jears. The bars 
are at least 10 meters thick in some places, and may contain as much as a million cubic meters of gravel and sand. Because the granite is highly jointed, the bedrock surface under the bars is very uneven, and there are many large boulders which would interfere with dredging operations. It is reported that the gold values are fairly constant in all the bars, but that the percentage of scheelite decreases downstream from Nacimiento. The highest assay of a reliable sample of the bar nearest Nacimiento gave 0.1 percent of $W_{3}$ and 2.00 pesos of gold per cublc meter, but this content is several times the average values.

El Trueno mine. - The El Trueno mine is about 10 kilometers west of Nacimiento. It was not examined by the author. The mine is in granite, and probably is a pegmatite dike similar to those at Nacsmiento. During 1916 and 1917 it jielded 40 tons of scheelite concentrates, according to Frank Fast, and was abandoned in 1917. Since then 1t has been worked intermittently by gambusinos, and the old workings are caved. Most of the gambusino production, which only amounts to a few tons of concentrate, came from the dumps and from nearby placers. The property was idle during most of 1943.

\section{Llano Colorado deposit}

Small stringers of scheolite-bearing pegmatite were discovered in 1943 in the hills about 7 kilometers north of Llano Colorado, a small settlement on the road between Hermosillo and Soyopa. A small body of granite intrudes quartzite and volcanic rocks, and the geology is similar to that of the La Dura deposits. Some scheelite was mined from shallow pits in bedrock but most of it was taken from the adjacent washes. About 150 kilograms of concentrates containing 35 percent of $\mathrm{WO}_{3}$ had been taken out by the end of 1943. The district has not been thoroughly prospected and in the future other deposits may be found.

\section{VEINS IN GRANITE}

The tungsten-bearing quartz veins are probably closely related in origin to the pegmatite dikes. Two such deposits, are known, the La Paz and the El Cobre. They lie at the mar-f gins of intrusive bodies of granlte, and the El Cobre veins are adjacent to a small body of pegmatite. The mineral assemblage, however, is different from that of the pegmatite dikes.

The La Paz and the El Cobre mines are in the Tecoripa district, about $100 \mathrm{kilometers} \mathrm{east} \mathrm{of} \mathrm{Hermosillo.} \mathrm{The} \mathrm{El} \mathrm{Cobre}$ deposit had been worked for its copper and molybdenum as early as 1910, but tungsten was not discovered there until 1942. The La Paz claims were located in 1943 on the westward extension of the veins of the abandoned Realito copper property.

\section{Mineralogy}

The gangue at the El Cobre mine is principally quartz and calcite. Metallic minerals are scheelite, chalcopyrite, molybdenite, pyrite, and a little powellite and chalcocite. Secondary iron oxides are prominent in the upper 40 feet of the veins. The La Paz veins contain pyrite and scheelite in a 
gangue of quartz and calcite. Assays showed the presence of a little gold in one shoot ard barite is found in another shoot, but not assoclated with scheelite. The Realito mine, which worked the same veins 300 neters east of the La Paz claims, produced chalcopyrite and gold in a matrix of magnetite, pyrite, specularite, and very little quartz. No feldspar, mica, or chlorite were noted in the veins of either property.

\section{Teccripa district}

Only two deposits of tingsten are known in the Tecorlpa district, the EI Cobre and the La Paz. The Alaska, Dieciséis, Veta Grande, La Verde, Amargosa, and Realito copper mines, ali in the same vicinity, were examined with the aid of an ultraviolet lamp but no scheelite was seen. The mineral deposits are all in steeply dipping quartz veins in granito near the periphery of the intrusive body.

El Cobre mine. - The El Cobre mine is 15 kllometers northwest of Tecoripa and $120 \mathrm{kl}$ lometers east of Hermosilio, from whence it may be reached by automobile. The property was first worked in 1910 for gold, sjliver, and copper. In 1923 the

International Minerals Synclicate did some exploratory work, and in 1937 additional work was done by the Peñoles Company. In 1943 the American Smelting \& Refining Company acquired the property from W. C. Taylor, Jr., and was doing some underground exploratory work at the encl of that year. Total production has been between 600 and 1,000 tons of ore containing copper, gold, silver, and molybdenum. Scrme of this ore must have contained some tungsten as well, but scheelite was not recognized in the mine unt11 1942 .

The country rock of the ore is fine-grained granite, with many local variations in cimposition and texture, which intrudes quartzite ( $\mathrm{fig}$. $\mathrm{I}_{1}^{\prime \prime}$ ). Near the contact is an irregular body of medium-grained pegniatite made up of quartz and pink orthoclase, much of it in kraphic intergrowth, black biotite and abundant epidote, but no scheelite.

The El Cobre vein s ystem includes a group of more or less paraliel, locally branching and curving veins which form a zone 15 meters wide and 230 meters long. Individual veins are from a few centimeters to 2 meters wide, and average about 1 meter wide. In the veins the greinite has been replaced by scheelite, chalcopyrite, pyrite, and nolybdenite in a matrix of quartz and calcite, and some pyrite ard chalcopyrite are disseminated through the granite for several meters away from the veins. Thin stringers and anhedra: crystals of 'scheolite are scattered through most of the veins lut are most prominent in two shoots at the southwestern end of the vein zone.

The workings consist of' two inclined shafts 43 meters deep and 120 meters apart, more than 200 meters of drifts and crosscuts, and several small stopes above the 21 -meter level.

The tungsten ore shoots probably contain 2.0 percent of $\mathrm{WO}_{3}, 1.0$ percent of $\mathrm{MOS}_{2}$, and as much as 6 percent of Cu. In the remainder of the veins there is 0.1 to 0.5 percent of $\mathrm{WO}_{3}$, from 0.1 to 1.0 percent Mos $_{2}$, and as much as 12 percent of Cu, according to a few assays. The two known tungsten shoots probably extend from the 21 -meter level to at least 10 meters below the 45-meter level, and may contain as much as 4,000 tons of 
ore within these limits. Tungsten mineralization is as strong on the 43-meter level as it is in the higher levels, and may continue considerably deeper than is now known.

La Paz deposit. - The La Paz tungsten deposit is about 8 kilometers east of the $\mathrm{El}$ Cobre mine and about $20 \mathrm{kllometers}$ north of Tecoripa. It can be reached by automobile from the El Cobre or from the road between Hermosillo and Soyopa.

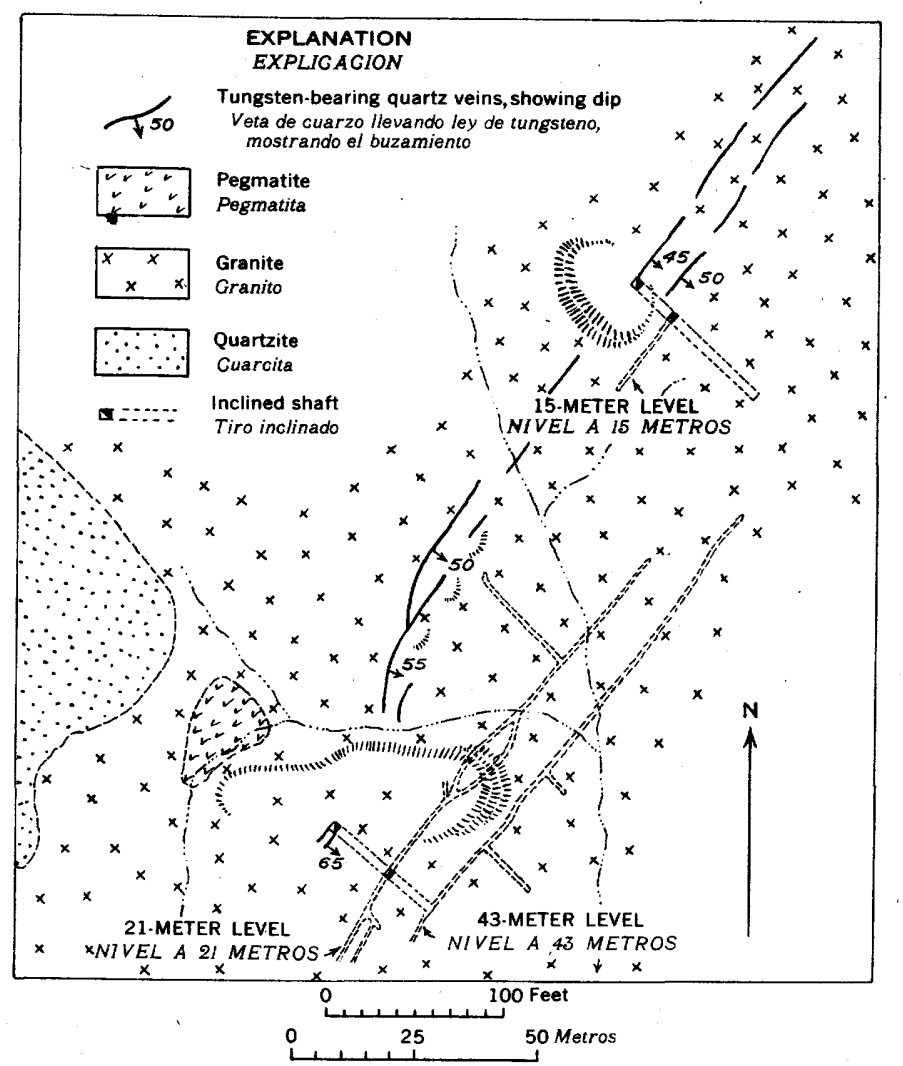

Figure 17.-Geologic sketch map of El Cobre mine, Tecoripe. district, Sonora.

The three claims of the La Paz group are owned by William C. Taylor, Jr., of Nogales, and cover the western extension of the veins of the old Realito copper mine. From April 1943 to the end of that year 15 pits were dug on the veins and 3 shafts were sunk, one to a depth of 20 meters, but no ore was shipped. There is no water on the property, and the nearest spring is at La Clénega, 5 kilometers east and at least 100 meters lower.

Tungsten occurs in a series of northeast-striking, vertically dipping replacement veins in granite. The veins consist of quartz, calcite, pyrite, and scheelite; one small shoot contains a little gold. The present exposures indicate about 3,000 tons of ore containing 2.0 percent of $\mathrm{WO}_{3}$ to $a$ depth of 20 meters, the depti of the deepest shaft. All workings were still in ore at the end of 1943 . 